\title{
X chromosome deletion in an Iranian woman with premature ovarian failure and a mini review
}

\begin{abstract}
Premature ovarian failure (POF) is a reproductive disorder which causes ovarian insufficiency before the age of 40, resulting in anovulating ovaries in approximately $1 \%$ of women with secondary amenorrhea and a slightly different prevalence among different ethnic populations. Decrease in gonadal estrogens and Inhibin besides elevated Luteinizing hormone ( $\mathrm{LH})$ and follicle stimulating hormone (FSH) are of well documented POF reasons. Moreover, a partial ovarian failure has been revealed to be associated with deficient germ cell development and complete ovarian dysfunction. POF patients experience a variety of genetic defects based of the heterogeneous nature of the disease. Some patients carry chromosome abnormalities, some are carriers of single gene defects and others have a mosaic pattern of a specific genetic anomaly in their body cell organization causing secondary amenorrhea. Half of the patients show temporary condition with spontaneous resumption of menses and normal FSH levels or normal pregnancy. Our goal of this article is to review POF cytogenetic abnormalities including X chromosome defects while introducing a new case of carrier POF for X chromosome deletion. In this case report, a new case of POF arising from $\mathrm{X}$ chromosome deletion is described as well as a review of the relevant literature, are presented. The patient provided written informed consent for this study. While genome wide association study is a promising tool for detection the ultimate genetic events resulting in POF, still easy access, cheap and informative cytogenetic methods are considered as the first priority in detecting POF causation.
\end{abstract}

Keywords: amenorrhea, premature ovarian failure, X chromosome
Volume 4 Issue 2 - 2017

\author{
Farkhondeh Pouresmaeili, ${ }^{1,2}$ Masoumeh \\ Fallahian,' Davood Zare Abdollahi² University of \\ 'Infertility and Reproductive Health Research Center (IRHRC). \\ Shahid Beheshti University of Medical Sciences, Iran \\ ${ }^{2}$ Department of Medical Genetics, Shahid Beheshti University of \\ Medical Sciences, Iran
}

Correspondence: Masoumeh Fallahian, Infertility and Reproductive Health Research Center (IRHRC), Faculty of Medicine, Shahid Beheshti University of Medical Sciences, Tehran, Iran,Tel 982I-22432558, Email pouresfar@gmail.com

Received: February 08, 2017 | Published: March 03, 2017

\section{Introduction}

Infertility is one of the major clinical problems which affect approximately $15 \%$ of couples, where $30 \%$ show women factors, $30 \%$ with men factors and $30 \%$ show involvement of the two. Another $10 \%$ infertility reason is explained to be idiopathic. Premature ovarian failure (POF, OMIM 311360), a different feature of female infertility has become an attractive subject for investigation due to its increasingly high incidence and the lack of effective cure. ${ }^{1}$ Premature ovarian failure is presently one of the clinical conflicts of our century, a common disease that affects approximately $1 \%$ of under 40 year old women. It is believed that $10-28$ percent of them prove primary amenorrhea $^{2}$ while $74-90 \%$ suffers of unknown etiology. ${ }^{3}$ The importance of the study of the genetic factors is undoubtedly a royal key for opening the minds to the blind section of the disease etiology. It is understood that apoptosis enhancement in aging ovaries, ${ }^{4}$ follicle maturation cessation, deficit of either granulosa or germ cells ${ }^{4,5}$ and activation of unripe follicles are involved in the POF creating pathway which is induced by the followings: Autoimmune diseases such as Hashimoto ${ }^{6}$ viruses like human papillomavirus and cytomegalovirus, surgery, chemotherapy, radiation, defects in chromosome $\mathrm{X}$ and consequent destruction/disruption and/ or deletion of X-linked genes (Turner syndrome and fragile X). ${ }^{7-9}$ Moreover, single gene defects and metabolic disorders including galactosemia, toxins and lifestyle factors like smoking could cause idiopathic POF. ${ }^{10,11}$ A group of these patients have normal pregnancy due to the possible occurrence of a cyclic ovarian function. ${ }^{12,13}$

\section{Diagnosis}

To confirm the disease status, further biochemical analysis of other hormones like free thyroxin, prolactin, TSH, testosterone, Karyotyping (under 30 years), breast and pelvic ultrasound are recommended. ${ }^{3}$ The measurement of other ovarian peptides that cause POF, such as Inhibin-B and anti mullerian hormone (AMH) is important for the diagnosis of the disease. Reduction in serum Inhibin-B before FSH elevation is thought to be a predictive sign for follicle reduction. ${ }^{14}$

\section{Abnormalities of $\mathbf{X}$ chromosome}

Since 2007, it is accepted that $\mathrm{X}$ chromosome has an essential role in ovarian function due to the involvement of its specific genes in the disease etiology except some with no effective influence. ${ }^{15}$ The abnormalities are presented in $5-10 \%$ of POF cases $^{1,16-20}$ partly in association to $\mathrm{X}$ inactivation skewing ${ }^{2,21,22}$ and some as deletions with a potential of developing secondary abnormalities such as duplications ${ }^{23}$ to generate haploinsufficiency in gene products ${ }^{24}$ or present a combined pattern of both anomalies. ${ }^{25}$ The deletion of the disease $\mathrm{X}$ linked genes is mostly related to the activation of follicle programming through growth of oocyte. ${ }^{26}$ However, due to the POF complex genetic nature, a review of the family history revealing the possible relationship between different parts of the genome in the disease susceptibility is essential. ${ }^{27}$ Several studies have shown that proximal $\mathrm{Xp}$ and $\mathrm{Xq}$ particularly $\mathrm{Xp} 11$ and $\mathrm{Xq} 13$ contain desired genetic information for the maintenance of the ovaries function. The researchers believe that the removal of these genomic areas will 
result in primary amenorrhea and POF. Association between POF and chromosomal abnormalities in mosaic $(45, \mathrm{X} ; 47, \mathrm{XXX})^{28}$ or non-mosaic state such as $46, X$, der (X) t $(X ; 19)$ (p21; q13), 46, X, $\mathrm{t}(\mathrm{X} ; 2)$ (q21; q14), 46, X, der (X) t (X; Y) (q25-26; q11.22) 46X, $\mathrm{t}(\mathrm{X} ; 13)(\mathrm{q} 13.3 ; \mathrm{q} 31)$, have been reported in different populations previously. ${ }^{1,29,30}$ Molecular cytogenetic analysis of Xq critical regions in premature ovarian failure has revealed that Ch.Xq21.31-q28 is an exciting genomic region with association to POF phenotype. ${ }^{9}$

\section{Case report}

A 37 year old woman was diagnosed as POF with approximate 6 months menstrual period cessation. She had married in 17 and had two daughters of 12 and 16 years old. She had all general menopause symptoms including hot flashes, vaginal dryness, heartthrob, anxiety and midnight sweeting. Besides anxious and being nervous, the patient was interested in knowing the status of her two daughters for possible inheritance of the disease. The patient's clinical reports of two previous miscarriages (curtage), two sesarians, ovarian cysts, sensitive kidneys, no autoimmune disease or hypertension. Her biochemical test confirmed her disease by FSH $>40 \mathrm{IU} / \mathrm{ml}$ and $\mathrm{LH}$ of menopausal range and slightly insufficiency in total vitamin D (CLIA), respectfully. Sonography revealed $63 \times 37 \times 32 \mathrm{~mm}$ uterus normal size, $5 \mathrm{~mm}$ endometrium thickness, the right ovary size $23 \times 13 \mathrm{~mm}$ and the left gonad $20 \mathrm{x} 10 \mathrm{~mm}$. She was taking supplement steroid hormones based on her gynecologist prescription.

After a complete genetic counselling with the patient and her husband, a third degree relative, filling a questionnaire and finding their agreement in cooperation for the research, peripheral blood from the woman was karyotyped with high resolution G-banding method and analysed. Stimated Band Resolution of the genetic test was 525 and chromosome setting showed a chromosome number of $46, \mathrm{XX}$ in the patient. Analysis of 20 sequential cells by Spectral Imaging system provided an $\mathrm{Xq}$ deletion, $\mathrm{Xq}^{21.1}$ to $\mathrm{Xq}^{23.1}$, in heterozygote state (Figure 1). Following to the identification of the aberrant chromosome in the woman, her daughters were karyotyped to show the possible transmission of the defective $\mathrm{X}$ chromosome. The results of the high resolution G-banding for these samples with stimated band resolution between 575 and 675 bands showed normal karyotypes.

\section{Discussion}

Deletions are known of the most common $\mathrm{X}$ chromosome abnormalities due to more breakpoints on $\mathrm{Xq}$ (between Xq13 and $\mathrm{Xq} 26)$ rather than $\mathrm{Xp} \cdot{ }^{31-33}$ Numerous $\mathrm{Xq}^{21.1-23.1}$ genes code for immunological factors involving in the maturation of the immune system and stimulation of growth development (Figure 2). For example, $C H M$ located on $\mathrm{Xq}^{21.2}$ plays a role in intracellular trafficking all over the body including gonads. ${ }^{34}$ The COL4A5 gene, produces type IV collagen fiber in making the basement membrane structure may participate in the cell permeability which in turn affects cell trafficking and cell cycle and perhaps POF involvement and egg production by ovaries. ${ }^{35}$ Also, PRPSI is a gene with activity in making purine and pyrimidines, the basic materials for cell viability. ${ }^{36}$ Breakage in the Xq13-26 and consequent events such as loss of genetic material, gene activation and/or inactivation during translocation, novel gene production by recombination potentially affect the process of ovarian function $^{37}$ through abnormal recombinant proteins generation or by position effect on other genes. ${ }^{38}$

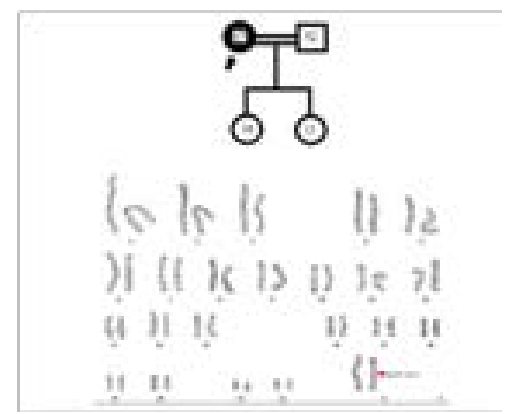

Figure I The family pedigree (top).Arrow indicates the proband. POF patient karyotype (bottom).

In the current introduced case as a non- musaic POF with chromosome deletion, the monoallelic chromosome abnormality in addition to probable other gene alterations could cause early menopause after two successful normal pregnancies. One explanation is that probably modified imprinting pattern of genes and altered gene expression in the aberrant chromosome caused such a premature ovarian failure. ${ }^{39} \mathrm{X}$-linked gene is required for ovarian development $t^{40}$ therefore; each of the discussed deleted genes from X chromosome could cause defective cell division directly or indirectly resulting in POF. Besides, centromeric heterochromatin area may influence the translocated genetic material to its neighbourhood through positional effect. ${ }^{41-48}$ Moreover, donor piece may positively/negatively influence the acceptor piece in the breakpoint when rejoining happens. The latter possibility may in term form a new recombinant coding area which in term separately or alongside with other abnormal events results in ovarian dysfunction and consequent POF which all need to be investigated in the future.

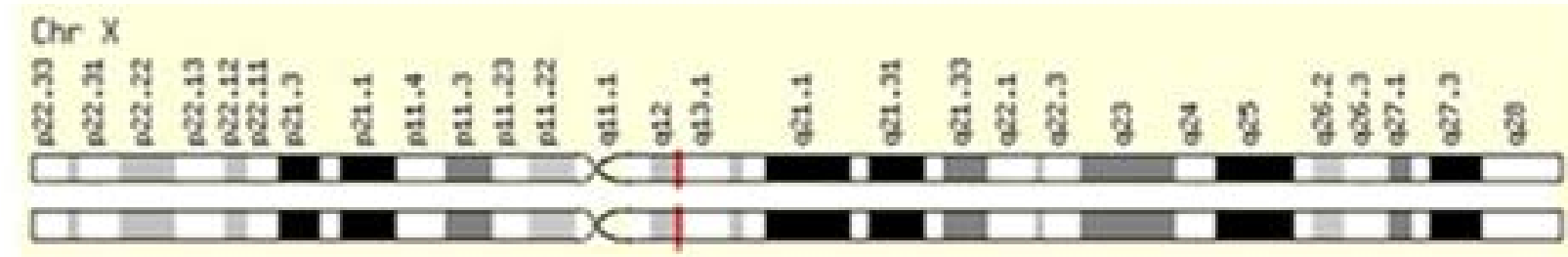

Figure 2 Chromosome $\mathrm{Xq}^{21.1-23.1}$ map according to NCBI-map viewer. 
Table 1 demonstrates some of the localized genes on $\mathrm{Xq}^{21.1-23.1}$ with their possible function. Our case analysis and the literature review confirm the idea that for perfect function, ovaries need two intact $\mathrm{X}$ chromosomes. Since still an effective treatment for POF is not known, clinical examination, differential characteristics of the symptoms and genetic counselling for early diagnosis are suggested as preventive ways for decreasing the rate of the disease specially in at risk women. To answer how imprinting pattern of genes, positional effect and recombinant genes formation following to the breakage and deletion in the aberrant chromosome, individually or in combination with each other, could cause premature ovarian failure needs further study in the future.

Table I Some of the localized genes on $\mathrm{Xq}^{21.1-23.1}$ with their possible function

\begin{tabular}{|c|c|c|c|c|}
\hline & Gene & $\begin{array}{l}\text { Chromosome } \\
\text { Location }\end{array}$ & Function & Reference \\
\hline I & ATP7A & $X q 21.1$ & $\begin{array}{l}\text { The reduced activity of these enzymes underlies the } \\
\text { characteristic features of occipital horn syndrome }\end{array}$ & Sismani et al. ${ }^{42}$ \\
\hline 2 & $\mathrm{CHM}$ & $\mathrm{Xq} 21.2$ & Intracellular trafficking & Jung et al. ${ }^{34}$ \\
\hline 3 & COL4A5 & $\mathrm{Xq} 22$ & Making the basment membrane structure & Srivastava et al. ${ }^{35}$ \\
\hline 4 & GLA & $\mathrm{Xq22}$ & Gives alpha-galactosidase A. an active enzyme in lysosomes & Pisani et al..$^{43}$ \\
\hline 5 & MAGTI & $X q 21 . I$ & $\begin{array}{l}\text { A magnesium transporter, which moves charged atoms (ions) } \\
\text { of magnesium }(\mathrm{Mg} 2+) \text { into certain immune system cells called } \\
\mathrm{T} \text { cells, intellectual disability }\end{array}$ & Trapani et al..$^{44}$ \\
\hline 6 & PLPI & $\mathrm{Xq22}$ & main proteins found in myelin & Masliah-Planchon et al..$^{45}$ \\
\hline 7 & POU3F4 & $X q 21 . I$ & $\begin{array}{l}\text { Play a role in determining cell types in the central nervous } \\
\text { system during early development and short stature. }\end{array}$ & Giordano et al..$^{46}$ \\
\hline 8 & PRPSI & Xq22.3 & Involved in making purine and pyrimidine nucleotides & Ugbogu et al. ${ }^{36}$ \\
\hline 9 & SERPINA7 & $\mathrm{Xq22.2}$ & $\begin{array}{l}\text { Important role in regulating growth, brain development, and } \\
\text { the rate of metabolism. }\end{array}$ & Domingues et al. ${ }^{47}$ \\
\hline 10 & TIMM8A & $X q 22.1$ & $\begin{array}{l}\text { Transports other proteins across the intermembrane space } \\
\text { to the mitochondrial inner membrane. }\end{array}$ & Cif et al. ${ }^{48}$ \\
\hline
\end{tabular}

\section{Conclusion}

This review confirms the unavoidable and essential role of $\mathrm{X}$ chromosome integrity in ovarian function and emphasis on the importance of cytogenetic tools for detection and better management of POF.

\section{Acknowledgement}

None.

\section{Conflicts of interest}

The author declares there is no conflict of interest.

\section{References}

1. Baronchelli S, Villa $\mathrm{N}$, Redaelli $\mathrm{S}$, et al. Investigating the role of $\mathrm{X}$ chromosome breakpoints in premature ovarian failure. Mol Cytogenet. 2012;5(1):32.

2. Conway GS. Premature ovarian failure. British medical bulletin. 2000;56(3):643-649.

3. Vujovic S, Ivovic M, Tancic-Gajic M, et al. Premature ovarian failure. Srp Arh Celok Lek. 2012;140(11-12):806-811.

4. Bukovsky A, Caudle MR. Immunoregulation of follicular renewal, selection, POF, and menopause in vivo, vs. neo-oogenesis in vitro, POF and ovarian infertility treatment, and a clinical trial. Reprod Biol Endocrinol. 2012;10:97.

5. Gougeon A. Present and future strategies for women at risk, or suffering from premature ovarian failure (POF)]. Gynecol Obstet Fertil. 2012;40(11):679-683.
6. Ott J, Pecnik P, Promberger R, et al. Dehydroepiandrosterone in women with premature ovarian failure and Hashimoto's thyroiditis. Climacteric. 2014;17(1):92-96.

7. Colafrancesco S, Perricone C, Tomljenovic L, et al. Human papilloma virus vaccine and primary ovarian failure: another facet of the autoimmune/inflammatory syndrome induced by adjuvants. Am J Reprod Immunol. 2013;70(4):309-316.

8. Rege G, Foidart JM, Nisolle M, et al. Premature ovarian failure, from genetics to clinical. Rev Med Liege. 2012;67(7-8):413-419.

9. Beke A, Piko H, Haltrich I, et al. Molecular cytogenetic analysis of Xq critical regions in premature ovarian failure. Mol Cytogenet. 2013;6(1):62.

10. Shelling AN. Premature ovarian failure. Reproduction. 2010;140(5):633641.

11. Jin M, Yu Y, Huang H. An update on primary ovarian insufficiency. Sci China Life Sci. 2012;55(8):677-686.

12. Kalantaridou SN, Nelson LM. Premature ovarian failure is not premature menopause. Ann N Y Acad Sci. 2000;900:393-402.

13. Meduri G, Massin N, Guibourdenche J, et al. Serum anti-Mullerian hormone expression in women with premature ovarian failure. Hum Reprod. 2017;22(1):117-123.

14. Beck-Peccoz P, Persani L. Premature ovarian failure. Orphanet $J$ Rare Dis. 2006;1:9.

15. Toniolo D, Rizzolio F. X chromosome and ovarian failure. Semin Reprod Med. 2007;25(4):264-271.

16. Castillo S, Lopez F, Tobella L, et al. The cytogenetics of premature ovarian failure. Rev Chil Obstet Ginecol. 1992;57(5):341-345. 
17. Portnoi MF, Aboura A, Tachdjian G, et al. Molecular cytogenetic studies of Xq critical regions in premature ovarian failure patients. Hum Reprod. 2006;21(9):2329-2334

18. Ceylaner G, Altinkaya SO, Mollamahmutoglu L, et al. Genetic abnormalities in Turkish women with premature ovarian failure. Int $J$ Gynaecol Obstet. 2010;110(2):122-124.

19. Janse F, KnauffEA, Niermeijer MF, et al. Similar phenotype characteristics comparing familial and sporadic premature ovarian failure. Menopause. 2010;17(4):758-765.

20. Lakhal B, Braham R, Berguigua R, et al. Cytogenetic analyses of premature ovarian failure using karyotyping and interphase fluorescence in situ hybridization (FISH) in a group of 1000 patients. Clin Genet. 2010;78(2):181-185.

21. Davison RM, Davis CJ, Conway GS. The X chromosome and ovarian failure. Clin Endocrinol (Oxf). 1999;51(6):673-679

22. Zinn AR. The X chromosome and the ovary. J Soc Gynecol Investig 2001;8(1 Suppl Proceedings):S34-S36.

23. Tachdjian G, Aboura A, Portnoi MF, et al. Cryptic Xp duplication including the SHOX gene in a woman with 46,X, $\operatorname{del}(\mathrm{X})(\mathrm{q} 21.31)$ and premature ovarian failure. Hum Reprod. 2007;23(1):222-226.

24. Ferreira SI, Matoso E, Pinto M, et al. X-chromosome terminal deletion in a female with premature ovarian failure: Haploinsufficiency of X-linked genes as a possible explanation. Mol Cytogenet. 2010;3:14.

25. Vitek WS, Pagidas $\mathrm{K}, \mathrm{Gu} \mathrm{G}$, et al. Xq;autosome translocation in POF: Xq27.2 deletion resulting in haploinsufficiency for SPANX. $J$ Assist Reprod Genet. 2003;29(1):63-66.

26. Reddy P, Liu L, Adhikari D, et al. Oocyte-specific deletion of Pten causes premature activation of the primordial follicle pool. Science. 2008;319(5863):611-613.

27. Correa FJ, Tavares AB, Pereira RW, et al. A new FOXL2 gene mutation in a woman with premature ovarian failure and sporadic blepharophimosisptosis-epicanthus inversus syndrome. Fertil Steril. 2010;93(3):e1003e1006.

28. Ayed W, Amouri A, Hammami W, et al. Cytogenetic abnormalities in Tunisian women with premature ovarian failure. $C R \mathrm{Biol}$. 2014;337(12):691-694.

29. Pouresmaeili F, Fallahian M, Azizi F, et al. Chromosomal abnormalities in women with Premature Ovarian Failure. Journal of Reproduction \& Infertility. 2007;8(2):142-148.

30. Pouresmaeili F, Fazeli Z. Premature ovarian failure: a critical condition in the reproductive potential with various genetic causes. Int J Fertil Steril. 2014;8(1):1-12.

31. Madan K. Balanced structural changes involving the human X: effect on sexual phenotype. Hum Genet. 1983;63(3):216-221.

32. Kim MK, Seok HH, Kim YS, et al. Molecular genetic and cytogenetic characterization of a partial $\mathrm{Xp}$ duplication and $\mathrm{Xq}$ deletion in a patient with premature ovarian failure. Gene. 2014;534(1):54-59.
33. Eggermann T, Meschede D, Schuler H, et al. Premature ovarian failure associated with a small terminal Xq deletion: narrowing the POF1 region down to Xq27.2/Xq27.3-qter. Clin Genet. 2005;67(5):434-437.

34. Jung YD, Huh JW, Kim DS, et al. Quantitative analysis of transcript variants of CHM gene containing LTR12C element in humans. Gene. 2011;489(1):1-5.

35. Srivastava AK, McMillan S, Jermak $C$, et al. Integrated STS/YAC physical, genetic, and transcript map of human Xq21.3 to q23/q24 (DXS1203-DXS1059). Genomics. 1999;58(2):188-201.

36. Ugbogu EA, Wippler S, Euston M, et al. The contribution of the nonhomologous region of Prs 1 to the maintenance of cell wall integrity and cell viability. FEMS yeast Res. 2013;13(3):291-301.

37. Szvetko A, Martin N, Joy C, et al. Detection of chromosome x; 18 breakpoints and translocation of the xq22.3;18q23 regions resulting in variable fertility phenotypes. Case Rep Genet. 2012;2012:681-747.

38. Toniolo D. X-linked premature ovarian failure: a complex disease. Curr Opin Genet Dev. 2006;16(3):293-300.

39. Hundscheid RD, Sistermans EA, Thomas CM, et al. Imprinting effect in premature ovarian failure confined to paternally inherited fragile $\mathrm{X}$ premutations. Am J Hum Genet. 2000;66(2):413-418.

40. Mackay S. Gonadal development in mammals at the cellular and molecular levels. Int Rev Cytol. 2000;200:47-99.

41. Minor A, Mohammed F, Farouk A, et al. Genetic characterization of two 46,XX males without gonadal ambiguities. J Assist Reprod Genet. 2008;25(11-12):547-552.

42. Sismani C, Donoghue J, Alexandrou A, et al. A prenatally ascertained, maternally inherited $14.8 \mathrm{Mb}$ duplication of chromosomal bands Xq13.2-q21.31 associated with multiple congenital abnormalities in a male fetus. Gene. 2013;530(1):138-142.

43. Pisani A, Visciano B, Russo R, et al. A novel GLA mutation in a Fabry family with glucose-6-phosphate dehydrogenase deficiency. $J$ Nephrol. 2012;25(4):582-585.

44. Trapani V, Shomer N, Rajcan-Separovic E. The role of MAGT1 in genetic syndromes. Magnes Res. 2015;28(2):46-55.

45. Masliah-Planchon J, Dupont C, Vartzelis G, et al. Insertion of an extra copy of Xq22.2 into 1p36 results in functional duplication of the PLP1 gene in a girl with classical Pelizaeus-Merzbacher disease. $B M C \mathrm{Med}$ Genet. 2015; 16:77.

46. Giordano M, Gertosio C, Pagani S, et al. A 5.8 Mb interstitial deletion on chromosome Xq21.1 in a boy with intellectual disability, cleft palate, hearing impairment and combined growth hormone deficiency. BMC Med Genet. 2015;16:74.

47. Domingues R, Font P, Sobrinho L, et al. A novel variant in Serpina7 gene in a family with thyroxine-binding globulin deficiency. Endocrine. 2009;36(1):83-86.

48. Cif L, Gonzalez V, Garcia-Ptacek S, et al. Progressive dystonia in MohrTranebjaerg syndrome with cochlear implant and deep brain stimulation. Mov Disord. 2013;28(6):737-738. 